\title{
New data on the distribution, biology and morphology of Asemum tenuicorne Kraatz, 1879 (Coleoptera: Cerambycidae), with new records from Poland
}

\author{
Jerzy M. Gutowski \& Jacek Kurzawa*
}

Gutowski, J. M. \& Kurzawa, J. 2019: New data on the distribution, biology and morphology of Asemum tenuicorne Kraatz, 1879 (Coleoptera: Cerambycidae), with new records from Poland. — Entomol. Fennica 30: 57-71. https://doi.org/ $10.33338 /$ ef. 82920

We report the discovery of the pyrophilous species, Asemum tenuicorne (Coleoptera: Cerambycidae) in the Białowieża Primeval Forest (NE Poland) in 2009 and 2016. This species was previously known only from Southern Europe and one locality detached from the main range on the island of Gotska Sandön in Southern Sweden. Information on its northern spread and current distribution is summarized and critically analyzed and new data on its biology are provided. The morphology of A. tenuicorne adults was studied using 46 specimens from different localities and compared with 63 specimens of the widely distributed Asemum striatum. Differences between the two species are presented and illustrated using external features, morphometric measurements, shape of the male copulatory organs and wing venation.

J. M. Gutowski, Forest Research Institute, Department of Natural Forests, 17230 Białowieża, Poland; E-mail: j.gutowski@ibles.waw.pl

J. Kurzawa (*corresponding author), Sterlinga 2/10, 97-200 Tomaszów Mazowiecki, Poland; E-mail: jacek.kurzawa@entomo.pl

Received 30 July 2018, accepted 30 October 2018

\section{Introduction}

The genus Asemum Eschscholtz, 1830 belongs to the tribe Asemini Thomson, 1860 in the subfamily Spondylidinae Audinet-Serville, 1832. This genus comprises nine species distributed in the Palaearctic region (A. arisanum Kano, 1930; A. lucidulum Pesarini \& Sabbadini, 1997; A. punctulatum Blessig, 1872 and A. tenuicorne Kraatz, 1879), Nearctic (A. australe LeConte, 1850; A. caseyi Linsley, 1957; A. glabrellum Bates, 1892 and $A$. nitidum LeConte, 1873) and Holarctic (A. striatum (Linnaeus, 1758)) (Monné 2006, Löbl \& Smetana 2010, Bezark 2016).

The distribution of longhorn beetles in Eu- rope is relatively well known (Bense 1995, Sama 2002, Löbl \& Smetana 2010, Danilevsky 2017). Two localities in Central and Northern Europe stand out in terms of species richness of saproxylic beetles, including Cerambycidae: Gotska Sandön (Sweden) and the Białowieża Primeval Forest (Poland / Belarus) (Gutowski \& Jaroszewicz 2001, Ehnström \& Axelsson 2002). Asemum tenuicorne is generally found in southern Europe but has also been known for many years in an isolated population on the island of Gotska Sandön.

On April 28, 2009, a ground-level fire occurred over about 7 ha of a 140-year-old natural forest stand in Białowieża National Park, affect- 


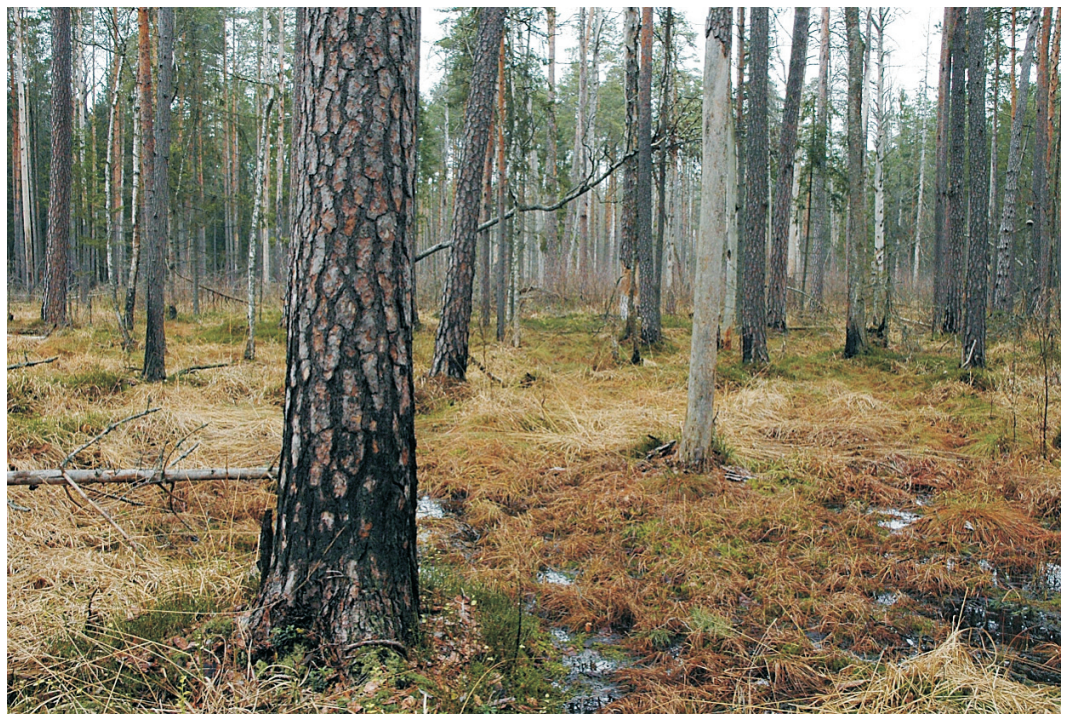

Fig. 1. Burned area in the Białowieża Primeval Forest where two specimens of Asemum tenuicorne were collected.

ing the following habitats: moist forest $(60.5 \%$ of the affected area), swampy forest $(24.5 \%)$, and mixed coniferous forest (13.2\%). This and other researches were undertaken to compare changes in species diversity, abundance and composition of beetles (with particular reference to saproxylic species) as a result of disturbance caused by the fire in the pine-spruce forest ecosystem. Activities carried out in these study areas were limited to observations and scientific research.

Starting just a few days after the fire, beetles were collected from the fire-affected area (Fig. 1) and from a similar stratum of forest unaffected by the fire, using Moericke traps (Moericke 1951), barrier traps of the Netocia type (Piętka \& Borowski 2015) and IBL-2 type traps (Borowski \& Marczak 2015). The collections occurred in 2009-2011 and 2015-2018. In the course of these studies, we collected two specimens of Asemum tenuicorne, a new species record from Poland.

Here we present a critical analysis of information in the literature on Asemum tenuicorne - a little-known cerambycid species, as well as new data on its distribution, morphology and biology.

\section{Materials and methods}

To examine as large number of specimens of $A$. tenuicorne as possible and to compare morphological characters with the sympatric species, $A$. striatum, we searched the entomological collections of the most important institutions in Poland (e.g. Institute of Systematics and Evolution of Animals, Pol. Acad. Sci., Kraków; Museum and Institute of Zoology, Pol. Acad. Sci., Warszawa; Museum of Natural History, Wrocław University, Wrocław) as well as private collections of the following entomologists: Paweł Górski (PG), Lech Karpiński (LK), Roman Królik (RK), Andrzej Lasoń (AL), Jerzy Ługowoj (J屯), Tomasz Olbrycht (TO), Radosław Plewa (RP), Wojciech Szczepański (WS), Marcin Szewczyk (MS), Jan Tatur-Dytkowski (JT-D), including the authors, J. M. Gutowski (JMG) and J. Kurzawa (JK).

In addition to the specimens from the Białowieża Primeval Forest, the following $A$. tenuicorne specimens from Italy and Greece were examined (b: black form, br: brown form):

Italy: $1 \hat{\jmath}$ (br) - Toscana: Firenze, Crespino di Marradi, leg. M. Benelli, ex larva: Pinus, sfarfallato it: V 05[05.2005], coll. RP; 2 + (b, br) - Emilia-Romagna: Casola Valsenio, ex. Pinus, VI.2016, leg. Casadio, coll. LK; 1 q (br), $2 \widehat{\jmath}$ (br) - Siena, Monte Amiata, 13.II.2004, leg. Benelli

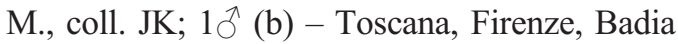
della Valle, 3.V.2010, leg. Benelli M., coll. JK; 5 ㅇ (br), $8 \hat{\jmath}$ (br), 7ð (b) - Toscana, Firenze, Casaglia, ex Pinus, 1-15.V.2010, leg. Benelli M., coll. JK.

Greece: 19 (br), 19 (b) - Thessaly, Mount Ossa, 1,300 m a.s.1., $39^{\circ} 50^{\prime} \mathrm{N}, 2^{\circ} 42^{\prime}$ E, 31.V.2016, leg. et coll. JK \& WS; 3 q (br), 2 q (b), $1 \lesssim$ (br), $3{ }^{\Uparrow}$ (b) 
Fig. 2. Adult females. - a. Asemum tenuicorne (Białowieża Forest). - b. A. striatum (Poland).

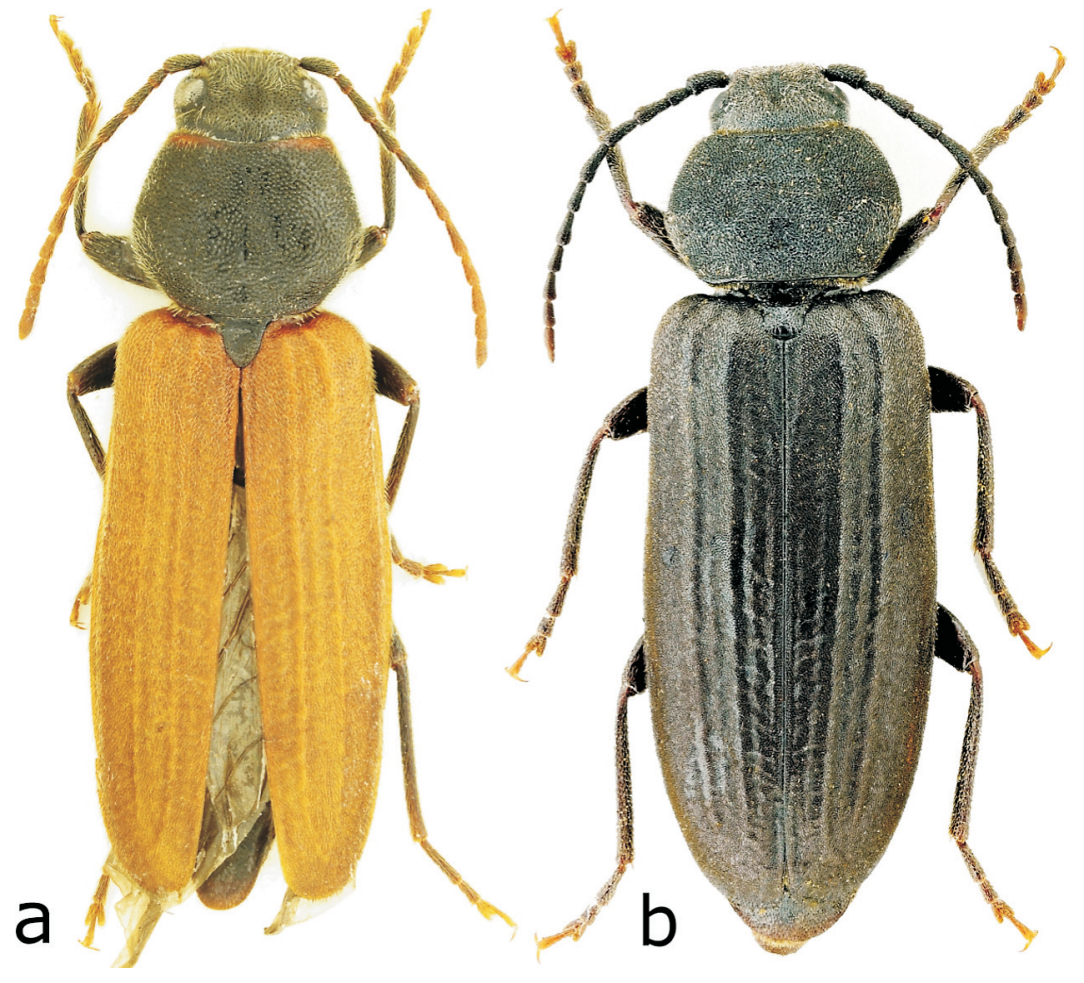

- Peloponnese, Taygetos mts., 1,086 m, 3 km SE Artemisia, $37^{\circ} 04^{\prime} \mathrm{N}, 2^{\circ} 14^{\prime} \mathrm{E}, 11 . \mathrm{VI} .2009$, leg. MS, coll. JK, AL, JŁ \& MS; 19 (b), $1 \overbrace{}^{\Uparrow}$ (br) Peloponnese, Taygetos: Neochori, 27.V.2010, leg. Martinů, coll. RP; 1 ( $(b), 1 \sigma^{\hat{~}}$ (br) Peloponnese: Neochori, Ag. Nikolaos, 1,300 m,

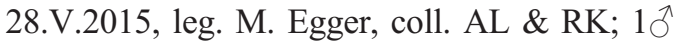
(br) - Peloponnese, [Taygetos mts.,] Ag. Vasileios - Artemisia, 13.VI.2009, leg. J. Kalisiak, coll. PG; 1 ㅇ (b) - Ellada, [Peloponnese], around Ag. Petros, 19.V.2009, under burnt bark of Pinus nigra Arn., JT-D leg. et coll.; $1 \delta^{\widehat{b}}$ (b) - Peloponnese, Paleopanagia, 14-15.VI.2006, leg. Martinů I., coll. JK.

All available specimens of $A$. tenuicorne (19, $27 \AA$ ) and $A$. striatum $(24+, 39 \AA)$ were examined and the following measurements taken: 1) the length of the left and right elytra, 2) the width of the prothorax at its widest point, 3 ) the length of the prothorax, 4) the combined maximum width of the elytra and 5) the length of the body from the apex of the mandibles to the posterior margin of the tergite VII. The measurements were made using two methods: directly, using a Carl Zeiss Jena
CITOVAL-2 stereoscopic microscope with a special measuring eyepiece with an accuracy of $0.1 \mathrm{~mm}$, and from photographs taken with a Wild Leica M8 microscope with a Nikon D7200 reflex camera using the ToupView program. Photographs of the wing venation for diagnostic purposes were made immediately after wet dissection of four specimens of each species.

Statistical calculations and charts were made using MS Office Excel 2013, R 3.5.0 and PAST 3.16 (Hammer et al. 2001). To compare differences between species and between sexes within species we used Generalized Linear Mixed Model (GLMM) with a Gaussian distribution for the response variable. Metric features of both species were correlated with each other and were difficult to analyze in one model. Therefore, the three most significant features were selected: body length, ratio of length and width of the prothorax, and ratio of length and width of the elytra. The distribution of body lengths did not deviate from normality, whereas values for both ratio features were log-transformed prior to analyses to achieve normality. The explanatory variables were species and sex, both as a two-level 
Table 1. Differential features of European species of genus Asemum.

Asemum tenuicorne

Body slender: proportion of length to width of elytral base on average 3.3 (Table 2)

Body flat in lateral view (especially elytra)

Sculpture of elytra fine, not wrinkled; transverse longitudinal costae less distinct

Frons slightly depressed, without furrow

Third, fourth and fifth segment of antennae distinctly longer than first segment of antennae (Figs 2a, 3a)

Third segment of antennae slender, $4.5 \times$ longer than width at apex (Figs 2a, 3a)

Antennal segments 3-9 almost parallel sided; width of base and width of apex nearly equal (Fig. 3a)

Pronotum less transverse: length to width 0.8 (Table 2, Fig. 10a), with gently rounded sides, shape less variable

Brown specimens with wide, light brown anterior margin of pronotum

Pubescence of pronotum light, dense, long, recumbent

Pronotum shining with sparse puncturation (Fig. 4a)

Third segment of hind tarsus bilobed nearly to the base

VII tergite of female long, apex slender, width to length 1.2 (Fig. 6a)

Aedeagus parallel-sided, apex distinctly swollen (Fig. 7c)

Parameres short, broadly rounded at apex, with short, sparse hairs (Fig. 7a)

Hind wing venation as in Fig. $5 \mathrm{a}$
Asemum striatum

Body broader: proportion of length to width of elytral base on average 3.7 (Table 2)

Body convex in lateral view (especially elytra)

Sculpture of elytra coarse, wrinkled, transverse; elytron with 2-4 longitudinal costae

Frons deeply depressed, with distinct bordered furrow

Third, fourth and fifth segment of antennae not longer than first segment of antennae (Figs 2b, 3b)

Third segment of antennae thick, 2.5-3 $\times$ longer than width at apex (Figs 2b, 3b)

Antennal segments 3-9 expanded at apex; base broader than apex (Fig. 3b)

Pronotum distinctly transverse: length to width 0.7 (Table 2, Fig. 10b), laterally angularly widened, shape of pronotum variable

Brown specimens only rarely with light brown anterior margin of pronotum

Pubescence of pronotum black, sparse, short, erected

Pronotum with dense, dull, granular puncturation (Fig. 4b)

Third segment of hind tarsus not bilobed in basal quarter

VII tergite of female wider than long, width to length 0.75 (Fig. 6b)

Aedeagus narrowed, conical towards apex

(Fig. 7d)

Parameres long, narrowed towards the apex, with long, dense hairs (Fig. 7b)

Hind wing venation as in Fig. $5 b$ factor; we were not interested in differences among the countries of origin of the specimens and in addition, for some of them the sample size was very small.

However, country was taken into account as a random variable. Initially we tested for interactions between the explanatory variables, but they were non-significant and thus we did not include them into final analyses presented here. Significance of fixed effects was estimated by t-tests using Satterthwaite's method for calculating degrees of freedom (package lmerTest, Kuznetsova et al. 2017). When reporting the test results we used following form: $t(d f)=t$-statistic with degrees of freedom, $p=$ significance value.

\section{Results}

\subsection{Asemum tenuicorne in the Białowieża Primeval Forest}

In the Białowieża Primeval Forest (Białowieża National Park, compartment 105B, UTM: FD95), we collected one female (June 2-15, 2009, 52॰48’53.89”N, 2350’33.45”E) (Fig. 2a) 
Table 2. Body proportions (ranges; means) of Asemum tenuicorne (At) $(n=46,19$,, $27 \AA)$ and $A$. striatum (As) adults $(n=63,24$ 우 $39 \overbrace{}^{\Uparrow})$.

\begin{tabular}{lccccc}
\hline & \multicolumn{2}{c}{ Pronotal index: length/width } & & \multicolumn{2}{c}{ Elytral index: length/width } \\
\cline { 2 - 3 } \cline { 5 - 6 } Sex & At & As & & At & As \\
\hline Males & $0.7-0.9(0.8)$ & $0.6-0.8(0.7)$ & & $2.2-2.6(2.4)$ & $2.0-2.4(2.2)$ \\
Females & $0.7-0.9(0.8)$ & $0.6-0.8(0.7)$ & & $2.2-2.4(2.3)$ & $2.0-2.3(2.2)$ \\
\hline Total & $0.7-0.9(0.8)$ & $0.6-0.8(0.7)$ & & $2.2-2.6(2.4)$ & $2.0-2.4(2.2)$ \\
\hline
\end{tabular}

Table 3. Measurements (mm, range (mean)) of adults of Asemum tenuicorne (At) $(n=46,19+27 \hat{\circ})$ and A. striatum (As) $(n=63,24$ 우 $39 \hat{)})$.

\begin{tabular}{|c|c|c|c|}
\hline & Males & Females & Total \\
\hline \multicolumn{4}{|c|}{ Body length } \\
\hline At & $10.4-17.3(13.2)$ & $12.0-17.8(15.1)$ & $10.4-17.8(13.9)$ \\
\hline As & $11.5-17.0(13.8)$ & $10.9-17.8(15.3)$ & $10.9-17.8(14.4)$ \\
\hline \multicolumn{4}{|c|}{ Length of right elytron } \\
\hline At & $6.8-11.2(8.5)$ & $7.4-11.4(9.2)$ & $6.8-11.4(8.8)$ \\
\hline As & $7.4-11.8(9.3)$ & $6.5-12.5(10.1)$ & $6.5-12.5(9.6)$ \\
\hline \multicolumn{4}{|c|}{ Width of pronotum } \\
\hline At & $2.4-4.2(3.1)$ & $2.9-4.3(3.5)$ & $2.4-4.3(3.3)$ \\
\hline As & $2.9-4.7(3.7)$ & $2.8-5.0(4.1)$ & $2.8-5.0(3.8)$ \\
\hline \multicolumn{4}{|c|}{ Length of pronotum } \\
\hline At & $2.0-3.1(2.5)$ & $2.1-3.3(2.7)$ & $2.0-3.3(2.6)$ \\
\hline As & $2.1-3.3(2.6)$ & $2.2-3.5(2.8)$ & $2.1-3.5(2.7)$ \\
\hline \multicolumn{4}{|c|}{ Width of elytra at base } \\
\hline At & $2.8-4.8(3.7)$ & $3.3-4.8(4.0)$ & $2.8-4.8(3.8)$ \\
\hline As & $3.4-5.2(4.3)$ & $3.2-5.5(4.6)$ & $3.2-5.5(4.4)$ \\
\hline
\end{tabular}

Table 4. Differences in hind wing venation of Asemum tenuicorne and A. striatum.

\begin{tabular}{lll}
\hline & Asemum tenuicorne & Asemum striatum \\
\hline $\begin{array}{l}\text { Margin rf at joint } \\
\text { with vein RA }\end{array}$ & Wide, pigmented & Not pigmented \\
Vein $\mathrm{AA}_{3}$ & Well developed, H-shaped & Short, invisible, X-shaped \\
Veins around rc & $\begin{array}{l}\text { Strongly pigmented, dark, } \\
\text { narrow rc field }\end{array}$ & $\begin{array}{l}\text { Narrow, weakly pigmented, bright, } \\
\text { wide rc field }\end{array}$ \\
Vein $\mathrm{R}_{3}$ & Long, dark, strongly pigmented & Short, light yellow \\
Vein $\mathrm{RP}$ & Long, dark, strongly pigmented, blurred & Shorter, light yellow, weakly pigmented \\
Vein $\mathrm{MP}_{3+4}$ & Thick, darkly pigmented & Thin, brightly pigmented \\
\hline
\end{tabular}

and one male (May 24-June 6, 2016, 52 49' $\left.0.35^{\prime \prime} \mathrm{N}, 23^{\circ} 50^{\prime} 35.39^{\prime \prime} \mathrm{E}\right)$ of Asemum tenuicorne in the "Netocia" barrier traps suspended on the trunks of live Scots pines Pinus sylvestris Linnaeus in the area of fire, leg. JMG. Both specimens belong to the form with brown elytra.

\subsection{Taxonomy}

Asemum tenuicorne was described by E. G. Kraatz in 1879 based on two specimens $\left(19,1{ }^{\Uparrow}\right)$ from Crimea. The types are stored in the collection of Senckenberg Deutches Entomologisches 

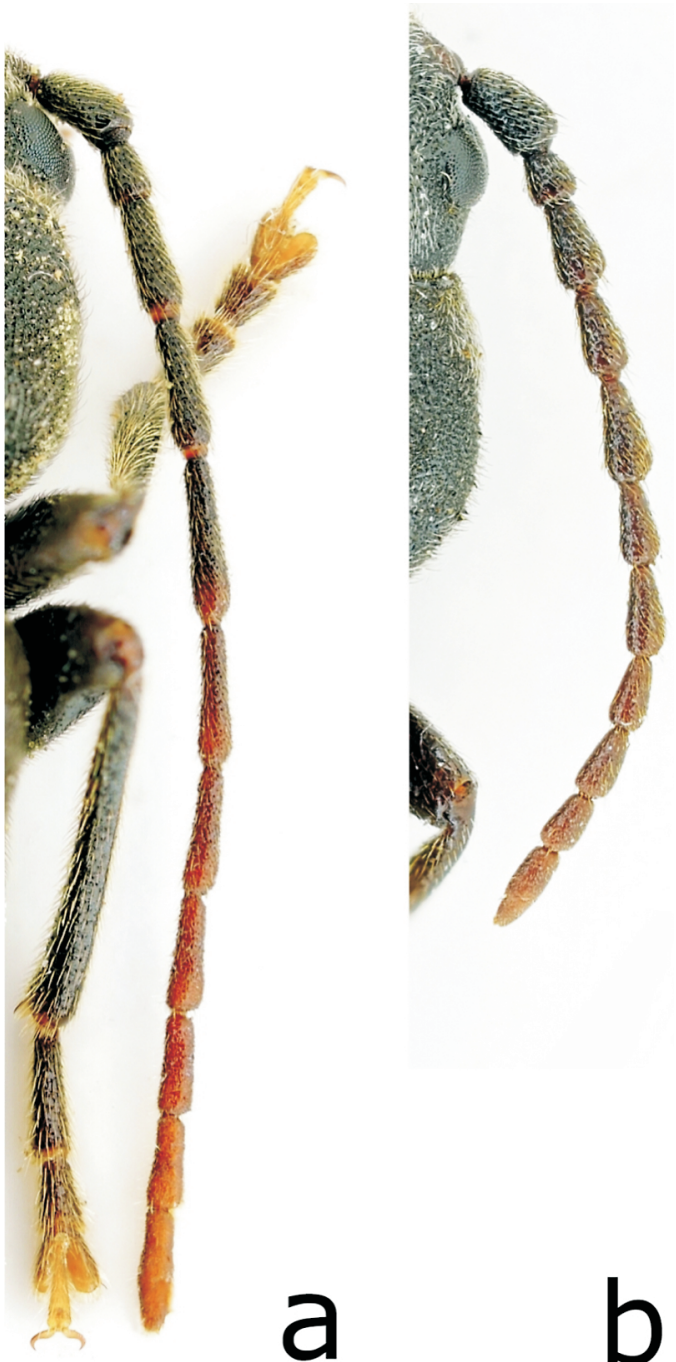

Fig. 3. Antennae of males. - a. Asemum tenuicorne. - b. A. striatum.

Institut in Müncheberg (previously the Deutsche Entomologische Institut in Eberswalde) (Sama \& Bocchini 1992). Recently, a new subspecies was described from south Turkey (İçel prov.), $A$. tenuicorne ssp. claricostulatum Özdikmen \& Aytar, 2012 (Özdikmen \& Aytar 2012).

The holotype ( $\left.\sigma^{\top}\right)$ is preserved in the Entomology Department of Eastern Mediterranean Forestry Research Institute (Turkey, Tarsus, İçel prov.).

Megasemum quadricostulatum var. semilividum Pic, 1893: 417 (loc. typ. Amanos Mountains in Hatay province, Turkey) is an unavailable name according to Özdikmen and Aytar (2012),
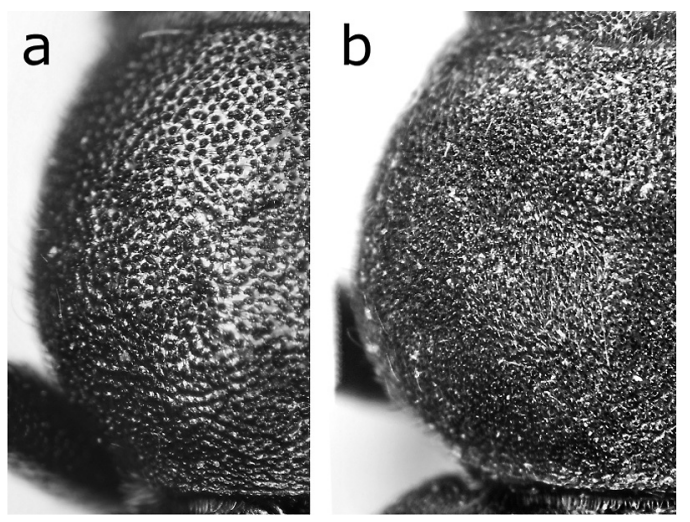

Fig. 4. Pronotal puncturation. - a. Asemum tenuicorne. - b. A. striatum.

who synonymized this with their newly described A. t. claricostulatum Özdikmen \& Aytar, 2012.

Özdikmen and Aytar (2012) separated the new subspecies claricostulatum from the nominative subspecies based on the following features: clearly longer antennae, the pedicel is as long as half of the third antennal segment, the prothorax is widest below the center $(2 / 5$ distance from base) and the costae on the elytra are more visible. However, we compared photos of type $A$. t. claricostulatum with a long series of $A$. $t$. tenuicorne (Greece, Italy, Poland) and found no consistent differences between them; i.e., there is much natural variability in the mentioned features within this species. Sama et al. (2012) recently recorded $A$. $t$. tenuicorne from Dörtyol (Hatay), near loc. typicus of $A$. t. var. semilividum Pic, 1893.

Casey (1912) described nine taxa from the genus Asemum mainly based on such features as the length of antennae and the shape of the prothorax, but all were subsequently synonymized. The variability of these features in the genus Asemum demands extreme caution in describing new taxa, especially at the level of subspecies.

\subsection{Morphology}

Distinguishing between adults of $A$. striatum and A. tenuicorne on the basis of existing keys can be difficult, and even unsuccessful, because they usually concern only few features, the interpretation of which is subjective (Plavilstshikov 1940, 1965, Pesarini \& Sabbadini 1994, Bense 1995, 
Fig. 5. Wing venation (right wing). - a. Asemum tenuicorne. - b. A. striatum. $\mathrm{AA}_{3}$ : anal anterior vein, $\mathrm{MP}_{3+4}$ : medial posterior vein, rc: radial cell, rf / RA: radial field at radial anterior vein, $\mathrm{R}_{3}$ radial vein, RP: radial posterior vein. Terminology according to KukalováPeck and Lawrence (1993, 2004).
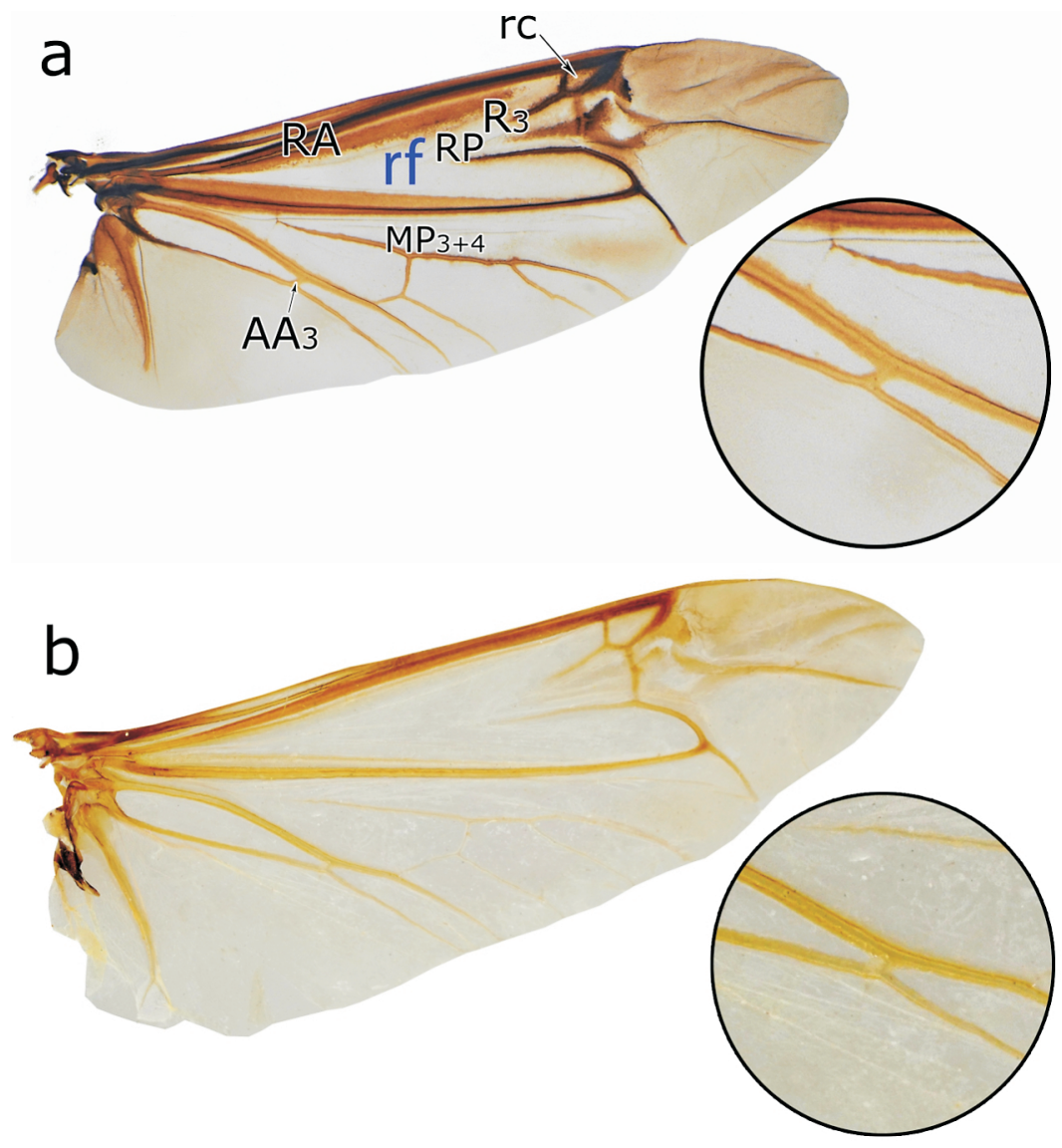

Bilý \& Mehl 1989). A somewhat more detailed key was provided by Sama and Bocchini (1992). The important features of $A$. tenuicorne are given in the description of Kraatz (1879). Specimens of both species are very variable (e.g. Fig. 2), which may make identification difficult. Based on the study of several dozen specimens of $A$. striatum and $A$. tenuicorne from different locations, and verification of the features given in the literature, we provide the most useful diagnostic features in the key in Table 1 and Figs 2-7.

The series of $A$. tenuicorne $(19+, 7$ black and 12 brown and $27 \hat{\jmath}, 15$ black and 12 brown) and A. striatum $(24$,, $39 \AA$ ) were compared (Tables 2-4). The species have overlapping size, but they differ in all the metric features included here. The average body length, without separating sexes, of A. tenuicorne $(13.92 \mathrm{~mm}, S D=1.98 \mathrm{~mm})$ is slightly, but significantly, less than that of $A$. striatum $(14.4 \mathrm{~mm}, S D=1.59 \mathrm{~mm}$; GLMM, $t(15.549)=-2.420, p=0.028$; Table 3$)$. Females
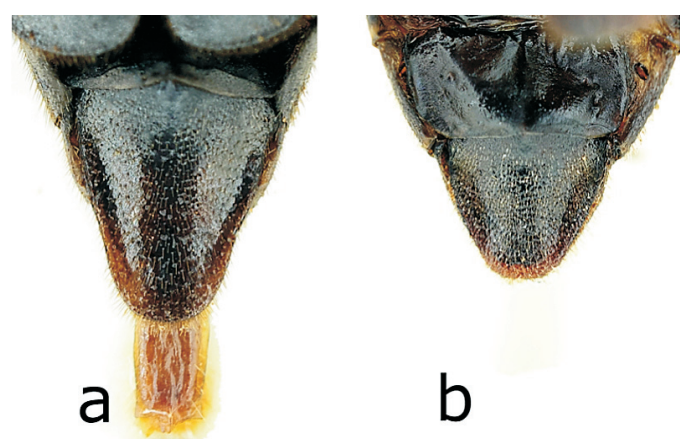

Fig. 6. VII sternite of female. - a. Asemum tenuicorne. -b. A. striatum.

are slightly larger than males in both species $(\mathrm{GLMM}, t(101.599)=-4.319, p<0.001$ for $A$. striatum, and $t(100.287)=-3.700, p<0.001$ for A. tenuicorne).

There was a statistically significant difference in body length in males $A$. striatum being slightly larger than $A$. tenuicorne (GLMM, $t(10.296)=$ $2.559, p=0.028$; Table 3, Figs 8, 9). In the gen- 


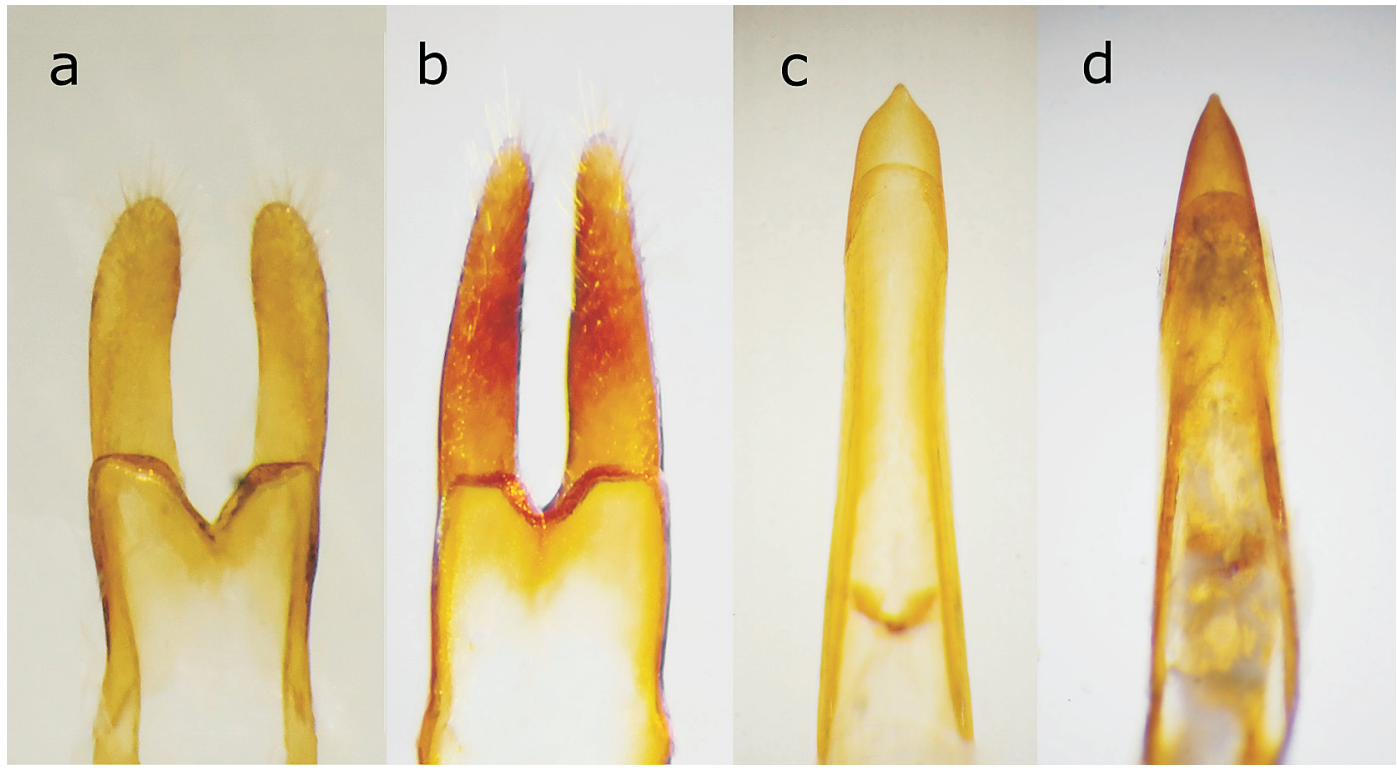

Fig. 7. Male copulatory organs: aedeagus and parameres. - a, c. Asemum tenuicorne. - b, d. A. striatum.

eral outline of the body, $A$. tenuicorne is slightly slimmer than $A$. striatum (elytra length / elytra width $=2.4)$ and it also has less transverse prothorax (length / width of the prefix $=0.8$ ), whereas in $A$. striatum these values are respectively 2.2 and 0.7 (Table 2 , Figs 9,10$)$. The differences between $A$. tenuicorne and $A$. striatum were statistically significant for both in elytra length/ width ratio $(\mathrm{GLMM}, t(6.678)=2.575, p=0.038)$ and in prothorax length/width ratio (GLMM, $t(3.940)=7.234, p=0.002)$.
The length of the left and right elytron in both species differed in some cases (fluctuating bilateral asymmetry), but these differences were slight, and there were too few specimens to perform a statistical analysis.

Wing venation may be a good diagnostic feature at the level of subfamilies (Vives et al. 2008), tribes, genera and also between species (Tian et al. 2013, Huang \& Chen 2016). After examining a series of specimens of $A$. tenuicorne and $A$. striatum, distinguishing features were found.

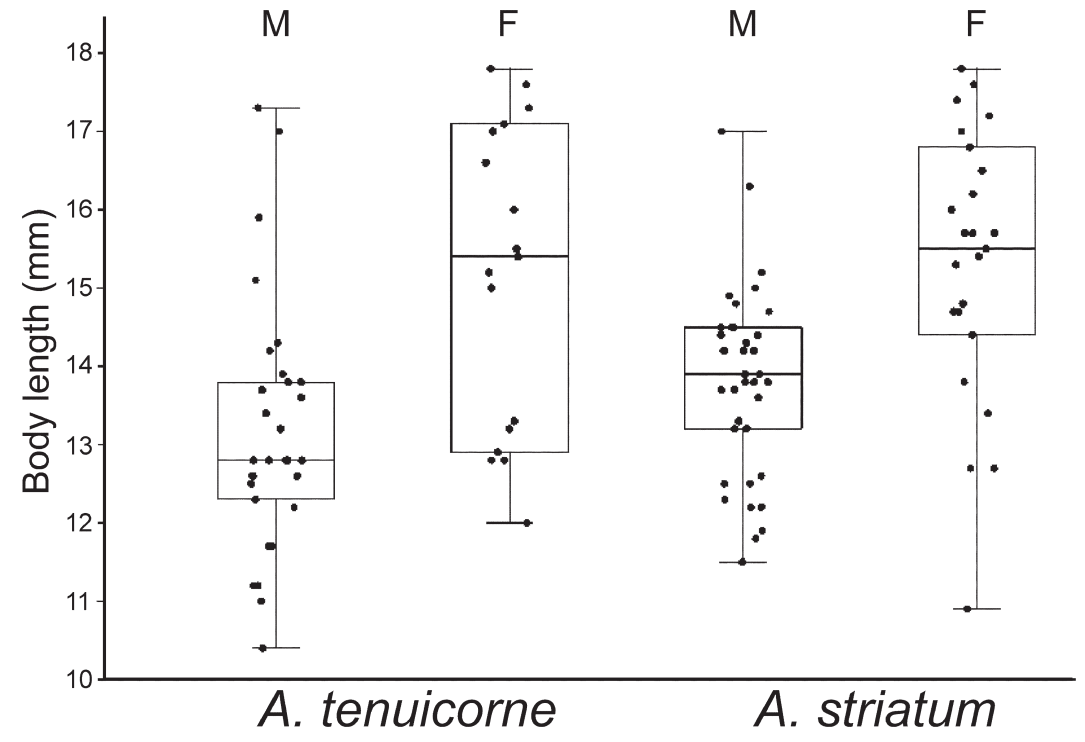

Fig. 8. Body lengths of Asemum tenuicorne and $A$. striatum males (M) and females (F). Medians, standard deviations (boxes) and ranges are shown. Differences between species and sexes are statistically significant, see section 3.3 
Fig. 9. Body proportions (length of elytra to width) of Asemum tenuicorne and $A$. striatum.

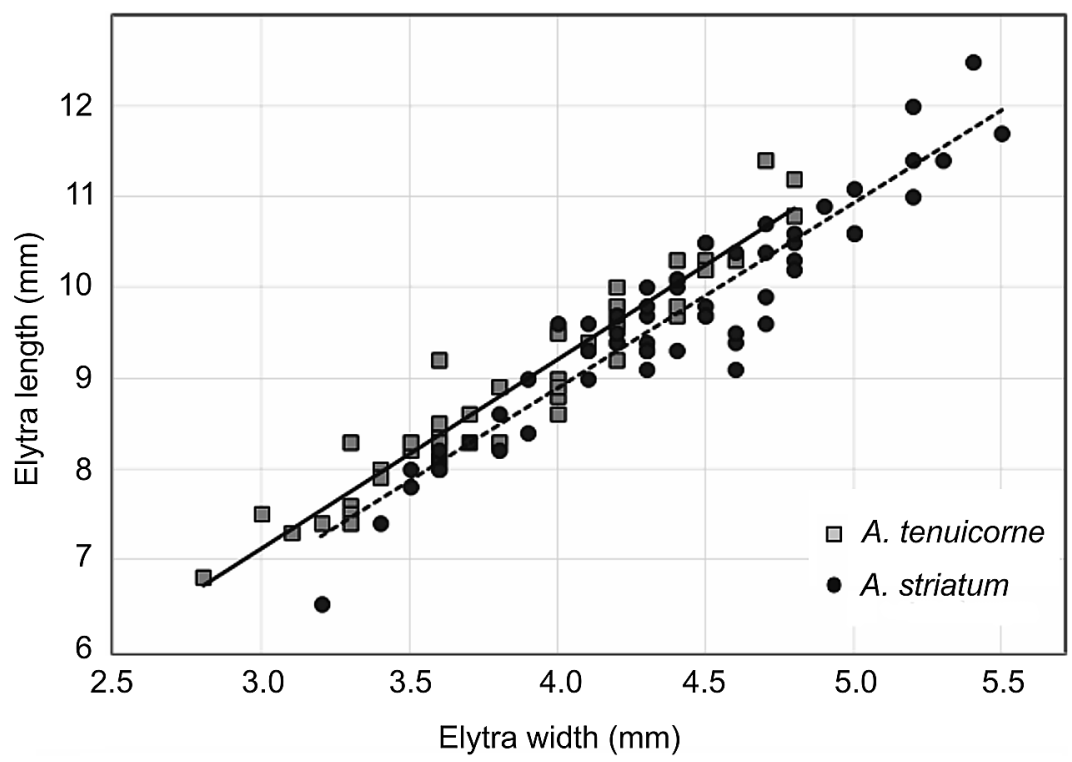

Asemum tenuicorne has a clearly darker wing picking thanks to the more developed pigmentation of the veins. In addition, the shape of the vein $\mathrm{AA}_{3}$ is different in these species (Table 4, Fig. 5).

The larva of $A$. tenuicorne was described by Mamaev and Danilevsky (1973) and completed by Švácha and Danilevsky (1987). The larvae are up to $20 \mathrm{~mm}$ long and $4 \mathrm{~mm}$ wide. They are easily distinguished from $A$. striatum by the urogomphi: those of $A$. tenuicorne are twice as long as their width at the base (in $A$. striatum, the length is equal to the width of the base), curved towards the front of the body (in A. striatum they are straight), and more strongly pigmented than those of $A$. striatum, i.e. the more heavily chitinized parts are browner. The egg and pupal stages have not been described yet.

\subsection{Biology}

Biology of $A$. tenuicorne is similar to that of $A$. striatum (Plavilstshikov 1940, Švácha \& Danilevsky 1987, Bense 1995).

The flight period is from May to July (Danilevsky \& Miroshnikov 1985, this study). Adults are active at dusk and at night (Lundberg 1981, Calvo Sánchez 2016, M. Szewczyk, this study) but they can also be found during the day in the cracks in the bark (Sama \& Bocchini 1992, this study).

Host plants of larvae are Pinus nigra (Sama \&

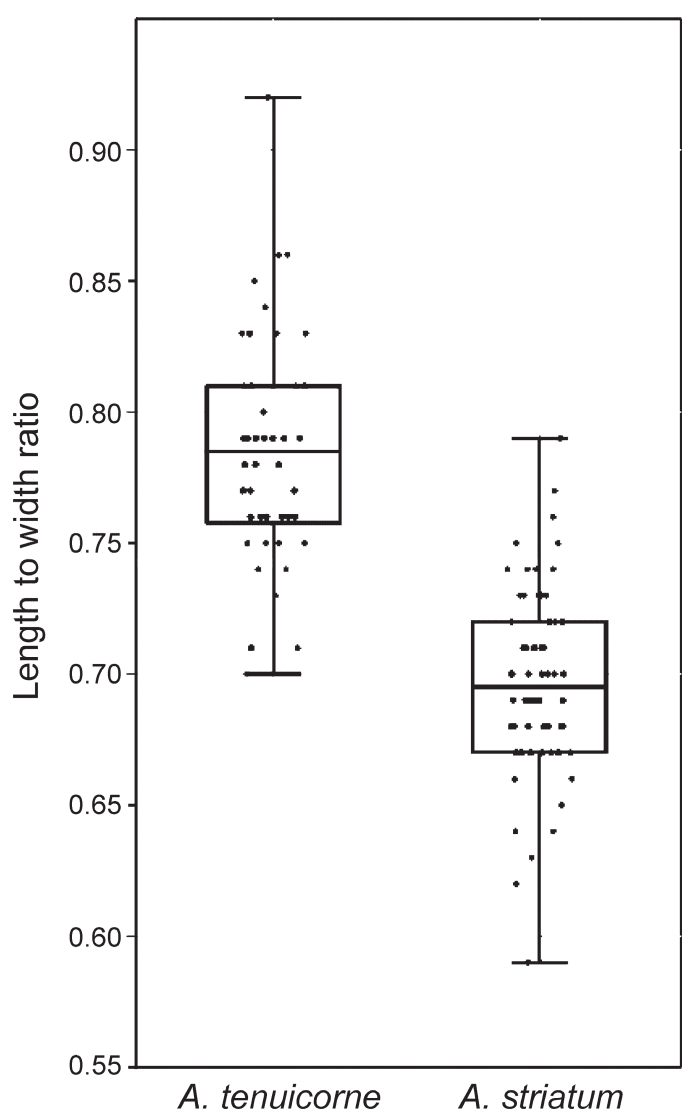

Fig. 10. Length to width ratio of prothorax of Asemum tenuicorne and $A$. striatum. Medians, standard deviations (boxes) and ranges are shown. Difference between species is statistically significant, see section 3.3. 


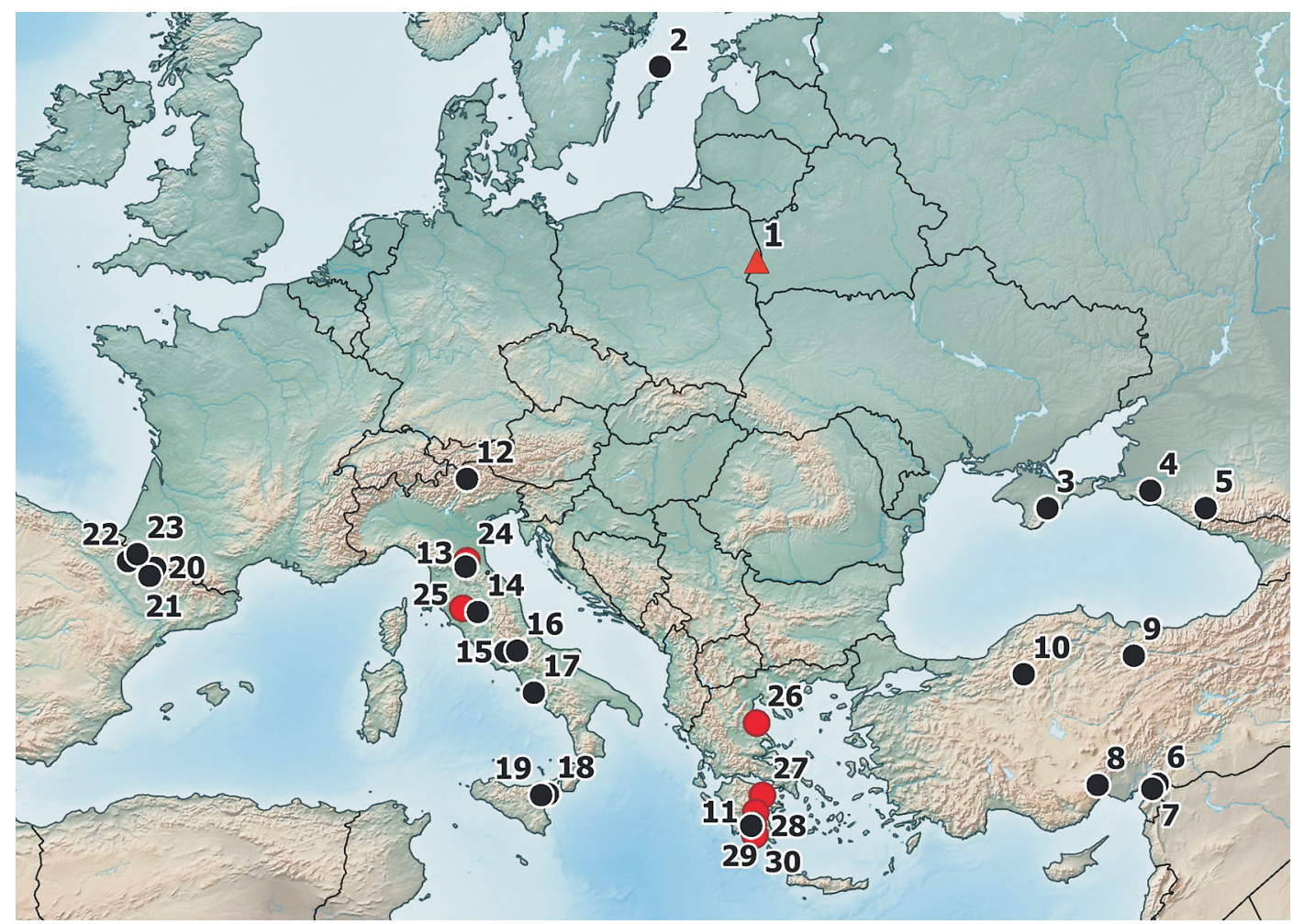

Fig. 11. Distribution of Asemum tenuicorne (red triangle: new record for fauna of Poland, black circle: literature data, red circle: new data, this study; *: this study). *1: PL, Białowieża Primeval Forest, 2: SE, Gotska Sandön (Heqvist 1955, Palm 1955, Lundberg 1981, Bilý \& Mehl 1989), 3: UK, Crimea (locus typicus) (Kraatz 1879), 4: RU, Ubinskaya (Mamaev \& Danilevsky 1973, Švácha \& Danilevsky 1987), 5: RU, Adygea, Gora Dzhuga (Miroshnikov 2011), 6: TR, Akbez (Pic 1893), 7: TR, Dörtyol (Sama et al. 2012), 8: TR, Dikenlioluk (loc. typ. A. $t$. claricostulatum Özdikmen \& Aytar, 2012), 9: TR, Tokat (Sama \& Bocchini 1992), 10: TR, Kızılcahamam (Demelt 1967), 11: GR, Taygetos (Sama \& Bocchini 1992, Danilevsky 2014), 12: IT, Bolzano (Kraatz 1887), 13: IT, Marradi (Sama \& Bocchini 1992, this study), 14: IT, Mt. Peglia (Sama 2005), 15: IT, Collepardo, Certosa di Trisulti (Gobbi 2002), 16: IT, Pescasseroli (Gobbi 2002), 17: IT, Mt. Faito (Sama \& Bocchini 1992), 18: IT, Sicilia, Linguaglossa (Sparacio et al. 2003, Baviera 2006), 19: IT, Sicilia, Piano Provenzana, Rifugio Ragabo (Rapuzzi \& Sama 2006), 20: SP, Valle de Ordesa, Oto de Broto (González Peña et al. 2007), 21: SP, Aineto (Murria Beltrán et al. 2013), 22: SP, Sierra de Leyre, Sierra de llion, Navarra (Calvo Sánchez 2016), 23: SP, Isaba Mt. Txamantxoia, Valle de Roncal, Navarra (Recalde Irurzun \& San Martin Moreno 2017), *24: IT, Casola Valsenio, *25: IT, Monte Amiata, *26: GR, Mt. Ossa, *27: GR, Peloponnese, Taygetos mts. (incl. Agios Vasileios), *28: GR, Peloponnese, Ellada, *29: GR, Peloponnese, Paleopanagia, *30: GR, Peloponnese, Neochori.

Bocchini 1992, Sama et al. 2012, this study), $P$. nigra var. calabrica (Loudon) C.K. Schneid. (Baviera 2006, Rapuzzi \& Sama 2006), P. nigra var. corsicana (Loudon) Hyl., P. heldreichii $\mathrm{H}$. Christ (BioLib 2016), Pinus (Mamaev \& Danilevsky 1973, Danilevsky \& Miroshnikov 1985, Bense 1995, Sláma \& Slámová 1996), or conifers in general (Danilevsky \& Miroshnikov 1985). According to Sama (2002), A. tenuicorne is monophagous on pine, and in Sweden and Poland most likely develops on $P$. sylvestris, because this is the only species of pine there. Eggs are laid on freshly dead trees (Sama 2002) and development to adults takes at least two years (Danilevsky \& Miroshnikov 1985).

The habitat, in which the specimens of $A$. tenuicorne were caught in the Białowieża Primeval Forest, is shown in Fig. 1. The first specimen was caught in the year of a forest fire and the second one seven years after the fire. In spite of targeted searches, we could not find the larvae of this species and their feeding places. 
So far, no parasitoid species of $A$. tenuicorne have been found. On the other hand, a case of predation has been recorded - one dead specimen was found on a wood belt in a web of an unspecified spider species (Greece, Peloponnese, Taygetos mts., SE Artemisia, M. Szewczyk, pers. comm.). Among the studied specimens of $A$. tenuicorne, we found (Greece, Peloponnese, Taygetos: Neochori, 27.V.2010) a specimen, on the body of which numerous deutonymphs of Trichouropoda sp. (Acarina: Mesostigmata: Uropodina) (det. J. Błoszyk) were observed attached to pro- and metafemur (phoresy).

\subsection{Geographical distribution}

The main sources summarizing the distribution of A. tenuicorne are published in the works of Sama and Bocchini (1992), Rapuzzi \& Sama (2006) and Danilevsky (2014). The current distribution of $A$. tenuicorne over the whole range is shown on a map (Fig. 11).

This species is known primarily from the south of Europe, southwest Asia but also from isolated localities in Sweden (Gotska Sandön island: Heqvist 1955, Palm 1955, Lundberg 1981, Bilý \& Mehl 1989) and Poland (Białowieża Primeval Forest, this study). It has been reported from the following countries: Spain (Aragón in the Pyrenees (Vives 1984, González Peña 2002, González Peña et al. 2007), Navarra (Calvo Sánchez 2016, Recalde Irurzun \& San Martin Moreno 2017)); Italy (Romagna toscana: Marradi (Sama \& Bocchini 1992, this study), Emilia-Romagna: Casola Valsenio (this study), Toscana: Monte Amiata (this study), Umbria: Monte Peglia (Sama 2005), Lazio: Collepardo, Monti Ernici: Certosa di Trisulti (Gobbi 2002), Abruzzo: Pescasseroli (Gobbi 2002), Campania: Monte Faito (Sama \& Bocchini 1992), Sicilia: Etna, Linguaglossa (Sparacio et al. 2003, Baviera 2006, Sama \& Rapuzzi 2011), Rifugio Ragabo, Piano Provenzana (Sama \& Rapuzzi 2011), Alto Adige: Bolzano (South Tirol, Bozen) (Kraatz 1887, Bertolini 1904, Heyden et al. 1906, Schilsky 1909, Plavilstshikov 1940)); Greece (Peloponnese, Mount Taygetos (Sama \& Bocchini 1992, Sláma \& Slámová 1996), Peloponnese: Artemisia, Agios Petros, Paleopanagia, Neochori (this study), Thesally: Mount
Ossa (this study)); Turkey (Ankara, Hatay (Demelt 1967), Tokat (Sama et al. 2012), Akbez (Kraatz 1879), Ýçel (Özdikmen \& Aytar 2012)); Georgia (Löbl \& Smetana 2010); SW Russia (Ubinskaja, Krasnodarskij Kraj (Mamaev \& Danilevsky 1973, Švácha \& Danilevsky 1987), Adygea, Gora Dzhuga (Miroshnikov 2011)); SE Ukraina (Crimea (Kraatz 1879, Plavilstshikov 1940).

The information on the occurrence of this species in Romania (Löbl \& Smetana 2010) is based on data with no references (Danilevsky 2014) and should therefore be removed from the list of species of this country. Several localities of $A$. tenuicorne based on Plavilstshikov's data are highly doubtful: Russia, Glavnyj Kavkazhskij Chrebet (Plavilstshikov 1940), Armenia, Giumri (Plavilstshikov 1948) and Turkey, Sarikamysh (Plavilstshikov 1927), Kars (Plavilstshikov 1931, 1940)). "N.N.Plavilstshikov wrongly regarded brown specimens of A. striatum (often very big!) from Russia, Teberda as A. tenuicorne. A big series of such specimens is preserved in his collection in Moscow and is available for study" (Danilevsky 2014, pers. comm.). Also, occurrence in Estonia (Murria Beltrán et al. 2013) is an evident mistake, and is not based on any documented findings.

Asemum tenuicorne has been sometimes confused with $A$. striatum (Baviera et al. 2005) and with Tetropium fuscum (Sánchez \& Tolosa 1998). However, both the recent literature information and the collected specimens indicate that A. tenuicorne is not as rare in its appropriate habitats as it seemed to date.

\section{Discussion}

Asemum tenuicorne was not previously known from Poland (Gutowski 2005, Kurzawa 2017) and its geographical range (south of Europe and the island of Gotska Sandön in Sweden) did not suggest that it would be present there. The second species of this genus, A. striatum, which occurs uncommonly but regularly in Poland, is known from the Białowieża Forest. In other regions of Poland, where pine forests dominate, A. striatum sometimes appears numerous and is often noted as a physiological and technical pest of conifers, especially pines (Dominik 1962). 
It may be discussed whether or not the populations from the Białowieża Primeval Forest, separated from the main range, and especially from Sweden, belong to a separate taxon, as suggested by Švácha and Danilevsky (1987). However, M. Sláma mentions (Sláma \& Slámová 1996) that he saw specimens from Gotska Sandön and confirms that they belong to A. tenuicorne. The specimens from the Białowieża Primeval Forest do not show differences in relation to the South European ones. There are no known details of $A$. tenuicorne biology, particularly the differences in preferences regarding the environment and microenvironment in relation to the common $A$. striatum, hence the potential habitat of $A$. tenuicorne larvae is difficult to predict. It is known from literature (Dominik 1962, Lundberg 1984) that $A$. striatum is a pyrophilous species. Probably A. tenuicorne can also be classified as such, because it is mainly associated with pines that tolerate ground-level fires and often fire improve the conditions for their effective renewal, because it eliminates competing species of trees (spruce, deciduous species), which are more sensitive to fire (Niklasson et al. 2010).

This is also confirmed by the circumstances of collecting the specimens originating from the southern part of the species range that we had at our disposal at the time of writing this work. One specimen was found in Greece, in the Peloponnese, under the bark of black pine Pinus nigra F. Arnold killed by fire (J. Tatur-Dytkowski leg.), and about 80 specimens that were collected on the logs of pine wood obtained from the extensive fire on this peninsula (J. Kalisiak, M. Kaźmierczak and M. Szewczyk leg.).

How did A. tenuicorne become established in the Białowieża Primeval Forest and the Gotska Sandön, both of which are clearly isolated from the main range? Colonization of these regions by A. tenuicorne must have occurred after the last glaciation at the end of the Pleistocene (Białowieża Primeval Forest) or during the Holocene (Gotska Sandön). Subfossil remains of this species in these locations in the last 12,000 years would clarify things but no such remnants have been found to date (Pawłowski 1989, Whitehouse 2006). However, early fossil records of other beetle species of similar biology related to Scots pine are plentiful. For example, the earliest records are: Acanthocinus aedilis (Linnaeus) 6,050 BP (Finland); Arhopalus rusticus (Linnaeus) 6,200 BP (Finland); Hylastes angustatus (Herbst) and H. ater (Paykull) 9,340 BP (Ireland); Pissodes piniphilus (Herbst) 5,900 BP (Finland); Rhyncolus elongatus (Gyllenhal) 10,650 BP (Great Britain), 8,500 BP (Ireland); and $R$. sculpturatus Waltl 5,350 BP (United Kingdom), 8,500 BP (Ireland) (Koponen \& Nuorteva 1973, Whitehouse 2006).

We suggest that $A$. tenuicorne should be regarded as a native species in Poland, because its introduction or recent arrival in the Białowieża Primeval Forest area is unlikely due to the compact, large area of the habitat, favorable conditions for its distribution, and its isolation from the nearest other known localities of this species in southern Europe and Sweden. The main host plant of A. tenuicorne, Pinus spp., has existed in Poland for 14,000 years and reached a peak during the period of 11,000-9,000 BP (Allerřd - beginning of the Holocene) (Latałowa et al. 2004). Pine occurred throughout the Holocene, but its prominence in the forests of Poland oscillated, and was lowest during the Atlantic and Subboreal periods, when deciduous species predominated. From about 3,000 BP, the amount of pine pollen in sediments began to increase, especially in the north-eastern part of Poland.

This process intensified in the last millennium, and is undoubtedly related to the industrialization of the country (Latałowa et al. 2004) and greater frequency of anthropogenic, ground-level forest fires (Niklasson et al. 2010). Fires, which are very favorable for the renewal of pine in the forests, also occurred without human influence in European landscapes in medium latitudes (not only in the south and in the north, as it is now), as evidenced by numerous coal particles found in early Holocene sediments (Whitehouse 2006).

Beetles associated with pine, including probably $A$. tenuicorne, inhabited these areas also in earlier times, e.g. in the interstadials of the Pleistocene (Cope 1965, Elias 2010), but subsequent glaciations displaced these species to refugia, from where they returned to their former areas. Taking these considerations into account, the colonization of the northern localities of this species might most probably have happened right after the last glaciation, during the period of maximum 
representation of pine in the landscape, i.e. 119,000 BP (Latałowa et al. 2004, Kullman \& Kjällgren 2006). Niklasson (2015), who researched the history of the fires at Gotska Sandön, states that the behaviour of $A$. tenuicorne and several other rare beetles on the island should be attributed to the lower intensity of forest use, frequent fires, open forest structure and a large amount of dead wood. On the land, in southern Sweden, these species probably became extinct over 150 years ago as a result of the human economy, before entomologists could register them.

We disagree with the prevailing opinion that this and other unique species of beetles preserved are relics of the warmer (Atlantic) Holocene period and claims that they arrived in Sweden, including this island, much earlier. In the Central European forests, which were intensively used in the historical period, and later forest management was carried out, the species became extinct. It remained only in the best preserved, long-protected remnants of natural forests with considerable shares of pine, as in the above-mentioned cases. This species is considered a forest relic (Palm 1955). It may be found in similar, best-preserved forests in Eastern Europe, which are not yet well researched.

Acknowledgments. We are grateful to dr. Karol Zub for help in statistical analyses of the data. For loans of material, we wish to thank the following colleagues: dr. Pawel Górski, dr. Lech Karpiński, Roman Królik, Andrzej Lasoń, Jerzy Ługowoj, dr. Tomasz Olbrycht, dr. Radosław Plewa, dr. Wojciech Szczepański, Marcin Szewczyk and Jan Tatur-Dytkowski. We are grateful to Prof. Jerzy Błoszyk for the designation of the phoretic Acarina's deutonymphs and to Agnieszka Kurzawa for invaluable help in translation of the manuscript into the English language and to dr. Jon Sweeney, who kindly revised the English translation of this paper. Our studies were partly funded by the Polish Ministry of Science and Higher Education, through the statute activity of the Forest Research Institute, in the frames of the project No. 240607.

\section{References}

Baviera, C. 2006: Coleotteri nuovi o poco noti di Sicilia III. (Carabidae, Histeridae, Cerambycidae, Chrysomelidae, Anobiidae, Bothrideridae, Tenebrionidae, Curculionidae, Scolytidae). - Il Naturalista siciliano: organo della Società siciliana di scienze naturali S. IV 30(1): 21-28. [In Italian.]

Bense, U. 1995: Longhorn beetles. Illustrated key to the
Cerambycidae and Vesperidae of Europe. - Weikersheim: Margraf. 512 pp.

Bezark, L. 2016: Checklist of the Oxypeltidae, Vesperidae, Disteniidae and Cerambycidae, (Coleoptera) of the Western Hemisphere. https://apps2.cdfa.ca.gov/ publicApps/plant/bycidDB/checklists/WestHemiCerambycidae2016.pdf (Site visited on 5 November, 2017).

Bilý, S. \& Mehl, O. 1989: Longhorn Beetles (Coleoptera, Cerambycidae) of Fennoscandia and Denmark. Fauna Entomologica Scandinavica 22. Leiden. 203 pp.

BioLib 2016: Asemum tenuicorne Kraatz, 1879. www.biolib.cz/en/taxon/id168794/ (Site visited on 5 December 2016).

Borowski, J. \& Marczak, D. 2015: Gilpinia fennica (Forsius, 1911) new to Poland (Hymenoptera, Symphyta: Diprionidae), and a review of the species. - Entomologica Fennica 26: 177-180.

Calvo Sánchez, F. 2016: Primeros registros de Asemum tenuicorne Kraatz, 1897 y Glaphyra marmottani (Brisout de Barneville, 1863) para Navarra (España) (Coleoptera: Cerambycidae). — Boletín de la Sociedad Entomológica Aragonesa 59: 271-272.

Casey, T. L. 1912: III — Studies in the Longicornia of North America. - Memoirs on the Coleoptera, Lancaster 3: 215-376.

Coope, G. R. 1965: Fossil insect faunas from Late Quaternary deposits in Britain. - Advancement of Science, March Issue: 564-575.

Danilevsky, M. L. 2014: Longicorn beetles (Coleoptera, Cerambycoidea) of Russia and adjacent countries. Part 1. - Higher School Consulting, Moscow. 518 pp. [In Russian.]

Danilevsky, M. L. 2017: A check-list of Longicorn Beetles (Coleoptera, Cerambycoidea) of Europe. Updated 05.05.2017. www.cerambycidae.net/europe.pdf, www.cerambycidae.net/europe_remarks.pdf (site visited on 3 December 2017).

Danilevsky, M. L. \& Miroshnikov, A. I. 1985: The Longicorn-Beetles of Caucasus (Coleoptera, Cerambycidae). An identification key. - Krasnodar. 428 pp. [In Russian.]

Demelt, C. v. 1967: Nachtrag zur Kenntnis der Cerambyciden-Fauna Kleinasiens. - Entomologische Blätter 63(2): 106-109. [In German.]

Dominik, J. 1962: Some investigations into the spread of Asemum striatum L. (Cerambycidae, Col.) and its control in Poland, its biology included. - Sylwan 106(5): 35-38. [In Polish with English summary.]

Ehnström, B. \& Axelsson, R. 2002: Insektgnag i bark och ved. - ArtDatabanken, Swedish University of Agricultural Sciences, Uppsala. 512 pp. [In Swedish.]

Elias, S. A. 2010: Advances in Quaternary entomology. Developments in Quaternary Sciences, Vol. 12, Elsevier. XIV+288 pp.

Gobbi, G. 2002: Su alcuni interessanti coleotteri xilofagi dell'Appennino centrale (Coleoptera, Buprestidae, Cerambycidae). - Bollettino dell'Associazione Romana di Entomologia 57, 1/4: 27-31. [In Italian.] 
González Peña, C. F. 2002: Catálogo de los Carambycidae (Coleoptera) de Aragón. - Catalogus de la entomofauna aragonesa 27: 3-43. [In Spanish.]

González Peña, C. F., Vives i Noguera, E. \& de Sousa Zuzarte, A. J. 2007: Nuevo catálogo de los Cerambycidae (Coleoptera) de la Península Ibérica, islas Baleares e islas atlánticas: Canarias, Açores y Madeira. — Sociedad Entomológica Aragonesa. Monografías 12: 5211. [In Spanish with English abstract.]

Gutowski, J. M. 2005: Longhorn beetles (Cerambycidae). - In: Bogdanowicz, W., Chudzicka, E., Pilipiuk, I. \& Skibińska, E. (eds), Fauna of Poland - characteristics and checklist of species. Vol. I: 49-53, 73-76. MiIZ PAN, Warszawa, 2004, 509 pp. [In Polish with English summary.]

Gutowski, J. M. \& Jaroszewicz, B. (eds) 2001: Catalogue of the fauna Białowieża Primeval Forest. - Instytut Badawczy Leśnictwa, Warszawa. 403 pp.

Hammer, $\check{R}$., Harper, D. A. T. \& Ryan, P. D. 2001: PAST: Paleontological Statistics Software Package for Education and Data Analysis. - Palaeontologia Electronica 4: 1-9.

Heqvist, K. J. 1955: Asemum tenuicorne Kr., en för Skandinavien ny långhorning (Col., Cerambycidae). Entomologisk Tidskrift 76(1): 58-59. [In Swedish.]

Heyden, L. v., Reitter, E. \& Weise, J. 1906: Catalogus coleopterorum Europae, Caucasi et Armeniae Rossicae. Editio secunda. - Berlin, Paskau, Caen. [VI]+774 pp.

Huang, G-Q. \& Chen, L. 2016: A revision of the genus Yoshiakioclytus Niisato, 2007 (Coleoptera: Cerambycidae: Cerambycinae: Anaglyptini). - Zootaxa 4179(3): 478-494. doi: https://doi.org/10.11646/zootaxa.4179.3.6

Koponen, M. \& Nuorteva, M. 1973: Über subfossile Waldinsekten aus dem Moor Piilonsuo in Südfinnland. - Acta Entomologica Fennica 29: 1-84. [In German.]

Kraatz, G. 1879: Ueber die Bockkäfer Ost-Sibiriens, namentlich die von Christoph am Amur gesammelten. - Deutsche entomologische Zeitschrift 23: 77-117. [In German.]

Kraatz, G. 1887: Asemum tenuicorne. - Deutsche entomologische Zeitschrift 31(2): 296. [In German.]

Kullman, L. \& Kjällgren, L. 2006: Holocene pine tree-line evolution in the Swedish Scandes: Recent tree-line rise and climate change in a long-term perspective. Boreas 35(1): 159-168. doi: https://doi.org/10.1080/ 03009480500359137

Kukalová-Peck, J. \& Lawrence, J. F. 1993: Evolution of the hind wing in Coleoptera. - The Canadian Entomologist 125(2): 181-258. doi: https://doi.org/ 10.4039/Ent125181-2

Kukalová-Peck, J. \& Lawrence, J. F. 2004: Relationships among coleopteran suborders and major endoneopteran lineages: Evidence from hind wing characters. European Journal of Entomology 101(1): 95-144. doi: https://doi.org/10.14411/eje.2004.018

Kurzawa, J. 2017. A checklist of longicorn beetles (Coleoptera: Cerambycidae) of Poland. [On-line] http:// www.entomo.pl/coleoptera/cerambycidae/index.php (Site visited on 3 December, 2017).

Kuznetsova, A., Brockhoff, P. B., Christensen, R. H. B. 2017. ImerTest Package: Tests in Linear Mixed Effects Models. - Journal of Statistical Software 82(13): 1-26. doi: https://doi.org/10.18637/jss.v082. i13

Latałowa, M., Tobolski, K. \& Nalepka, D. 2004: Pinus L. subgenus Pinus (subgen. Diploxylon (Koehne) Pilger) - Pine. - In: Ralska-Jasiewiczowa, M., Latałowa, M., Wasylikowa, K., Tobolski, K., Madeyska, E., Wright, H. E. Jr. \& Turner, C. (eds), Late glacial and Holocene history of vegetation in Poland based on isopollen maps: 165-177. W. Szafer Institute of Botany, Polish Academy of Sciences, Kraków. 444 pp.

Löbl, I. \& Smetana, A. (eds) 2010: Catalogue of Palaearctic Coleoptera 6: Chrysomeloidea. - Apollo Books, Stenstrup. 924 pp.

Lundberg, S. 1981: Gotska Sandöns skalbaggsfauna - nytillskott och intressanta arter. - Entomologisk Tidskrift 102(4): 147-154. [In Swedish.]

Lundberg, S. 1984: Den brända skogens skalbaggsfauna i Sverige. - Entomologisk Tidskrift 105(4): 129-141. [In Swedish.]

Mamaev, B. M. \& Danilevsky, M. L.1973: New data on systematic status of the subfamily Aseminae (Coleoptera, Cerambycidae) with reference to the morphology of larvae. - Zoologicheskij Zhurnal 52: 1257-1261. [In Russian with English summary.]

Miroshnikov, A. I. 2011: Family Cerambycidae - Longhorn beetles. - In: Zamotajlov, A. S. \& Nikitsky, N. B. (eds), Coleopterous insects (Insecta, Coleoptera) of Republic of Adygheya (annotated catalogue of species): 239-263. Fauna conspecta of Adygheya No 1. Maykop, Adyghei State University Publishers, 2010. 404 pp. [In Russian.]

Moericke, V. 1951: Eine Farbafalle zur Kontrolle des Fluges von Blattlausen, insbesondere der Pfirsichblattlaus, Myzodes persicae (Sulz.). - Nachrichtenblatt des Deutschen Pflanzenschutzdienstens 3: 23-24. [In German.]

Monné, M. A. 2006: Catalogue of the Cerambycidae (Coleoptera) of the Neotropical Region. Part III. Subfamilies Parandrinae, Prioninae, Anoplodermatinae, Aseminae, Oxypeltinae, Spondylidinae, Lepturinae and addenda to the Cerambycinae and Lamiinae. - Zootaxa 1212: 1-244. doi: https://doi.org/10.11646/zootaxa.1212.1.1

Murria Beltrán, Á., Murria Beltrán, F., Tolosa Sánchez, L. \& Corraleño Iñarra, A. 2013: Nuevos datos para el catálogo de los cerambícidos (Coleoptera: Cerambycidae) de Aragón (NE Península Ibérica). 3Ş nota. Arquivos Entomolóxicos 9: 175-182. [In Spanish with English abstract.]

Niklasson, M. 2015: Skogshistoria och bränder på Gotska Sandön. — Rapporter om natur och miljö nr 2015:1. Länsstyrelsen i Gotlands Län. Visby, Sweden. 58 pp. [In Swedish with English summary.]

Niklasson, M., Zin, E., Zielonka, T., Feijen, M., Korczyk, A. F., Churski, M., Samojlik, T., Jędrzejewska, B., 
Gutowski, J. M. \& Brzeziecki, B. 2010: 350-year treering fire record from Białowieża Primeval Forest, Poland: implications for Central European lowland fire history. - Journal of Ecology 98: 1319-1329. doi: https://doi.org/10.1111/j.1365-2745.2010.01710.x

Özdikmen, H. \& Aytar, F. 2012: A new subspecies of Asemum tenuicorne Kraatz, 1879 from Turkey (Coleoptera: Cerambycidae). — Munis Entomology \& Zoology 7(2): 1252-1255.

Palm, T. 1955: Coleoptera med isolerad nordeuropeisk förkomst i Sverige. - Opuscula Entomologica 20: 105-131. [In Swedish.]

Pawłowski, J. 1989: Beetles - Coleoptera. In: Kowalski, K. (ed.), History and evolution of terrestrial fauna of Poland. - Folia Quaternaria 59-60: 21-41. [In Polish.]

Pesarini, C. \& Sabbadini, A. 1994: Insetti della Fauna Europea Coleotteri Cerambicidi. - Natura, Rivista di Scienze Naturali, Museo Civico di Storia Naturale di Milano 85: 1/2: 1-132. [In Italian.]

Pic, M. 1893: Voyage de M. Charles Delagrange dans la Haute-Syrie. - Annales de la Société Entomologique de France 61: 413-422. [In French.]

Piętka, J. \& Borowski, J. 2015. Substrat trocinowy z grzybnią w pułapkach do odłowu chrząszczy mycetobiontycznych. - Studia i Materiały CEPL w Rogowie 17, 44(3): 165-172. http://yadda.icm.edu.pl/yadda/element/bwmeta1 .element.agro-0a0169df-11e9487b-a9af-e8b6ce20222c/c/Pietka_Borowski.pdf (Site visited on 15 May, 2018). [In Polish.]

Plavilstshikov, N. N. 1927: Ueber die eurasiatischen Asemum-Arten (Col., Ceramb.). — Entomologische Mitteilungen (Berlin) 16: 190-192. [In German.]

Plavilstshikov, N. N. 1940: Nasekomye zhestkokrylye. Zhuki-drovoseki [Beetles. Longicorn beetles]. - Izdatel'stvo AN SSSR, Moskva - Leningrad, 22, 2: XIV+785 pp. [In Russian.]

Plavilstshikov, N. N. 1948: Opredelitel' zhukov-drovosekov Armenii [A Key of Longicorn Beetles of Armenia]. Erevan. 232 pp. [In Russian.]

Plavilstshikov, N. N. 1965: Opredelitel' nasekomykh evropejskoj chasti SSSR. II. Zhestkokrylye i veerokrylye [A Key of Insects of European part of USSR. II. Beetles and Strepsiptera]. - Izdatel'stvo "Nauka", Moskva - Leningrad. 668 pp. [In Russian.]

Rapuzzi, P.\& Sama, G. 2006: Cerambycidae nuovi o interessanti per la fauna di Sicilia. New or interesting Cerambycidae from Sicily. — Quaderno di Studi e Notizie di Storia Naturale della Romagna 23: 157-172. [In Italian with English Abstract.]

Recalde Irurzun, J. I. \& San Martin Moreno, A. F. 2017: On the occurrence of Hallomenus (Hallomenus) axillaris (Illiger, 1807) in the Iberian Peninsula, confirmation of Ochina (Dulgieris) latreillii (Bonelli, 1812) and Platysoma (Cylister) lineare Erichson, 1834, and other remakable coleoptera of a south-pyrenean forest of Pinus sylvestris. - Revista gaditana de Entomología VIII(1): 53-66.

Sama, G. 2002: Atlas of the Cerambycidae of Europe and the Mediterranean Area. Volume 1: Northern, Wes- tern, Central and Eastern Europe, British Isels and Continental Europe from France (excl. Corsica) to Scandinavia and Urals. - Nakladatelstvi Kabourek, Zlin. 173 pp. +36 plates.

Sama, G. \& Bocchini, R. 1992: Asemum tenuicorne Kraatz, 1879 specie nuova per la Romagna e per la fauna Italiana (Coleoptera, Cerambycidae). - Quaderno di studi e notizie di storia naturale della Romagna 1: 19-25. [In Italian with English summary.]

Sama, G. \& Rapuzzi, P. 2011: Una nuova Checklist dei Cerambycidae d'Italia (Insecta Coleoptera Cerambycidae). A new Checklist of the Cerambycidae of Italy. Quaderno di Studi e Notizie di Storia Naturale della Romagna 32: 121-164. [In Italian with English abstract.]

Sama, G., Rapuzzi, P. \& Özdikmen, H. 2012: Preliminary report of the entomological surveys $(2010,2011)$ of G. Sama and P. Rapuzzi to Turkey (Coleoptera: Cerambycidae). - Munis Entomology \& Zoology 7(1): 2245.

Sánchez, M. Á. \& Tolosa, L. 1998: Primera cita de Isarthron fuscum (Fabricius, 1787) para la Península Ibérica (Coleoptera: Cerambycidae). First record of Isarthron fuscum (Fabricius, 1787) for the Iberian Peninsula (Coleoptera: Cerambycidae). - Zapateri Revista aragonesa de Entomologia 8: 197-198. [In Spanish with English abstract.]

Sláma, M. \& Slámová, J. 1996: Contribution to the recognition of Greek and Yugoslavian longicorn beetles (Coleoptera, Cerambycidae). — Biocosme Mésogéen, Nice 12(4): 117-143.

Sparacio, I., Bella, S. \& Turrisi, G. F. 2003: Nuovi dati su Buprestidae e Cerambycidae di Sicilia. - Naturalista siciliano S. IV, 27: 161-168. [In Italian.]

Švácha, P. \& Danilevsky, M. L. 1987: Cerambycoid larvae of Europe and Soviet Union (Coleoptera, Cerambycoidea). Part 1. - Acta Universitatis Carolinae. Biologica 30 (1986): 1-176.

Tian, L. C., Chen, L. \& Li, Z. 2013: Comparative study of hind-wing venation of Cerambycinae (Coleoptera, Cerambycidae) from China. - Acta Zootaxonomica Sinica 38(1): 1-15.

Vives, E. 1984: Cerambícidos (Coleoptera) de la Península Ibérica y de las Islas Baleares. Cerambicyds (Col. Cerambycidae) of the Iberian Peninsula and Balearic Islands. - Colección: Treballs del Museu de Zoología, no. 2. Barcelona. 137 pp. [In Spanish with English abstract.]

Vives, E., Drumont, A., Komiya, Z. \& Heffern, D. 2008: The New Caledonian genus Acideres Guérin-Méneville, 1858: systematic notes, sexual dimorphism and geographic distribution (Coleoptera, Cerambycidae). - Les Cahiers Magellanes 84: 1-16, 20 figs +2 tables.

Whitehouse, N. J. 2006: The Holocene British and Irish ancient forest fossil beetle fauna: implications for forest history, biodiversity and faunal colonization. Quaternary Science Reviews 25: 1755-1789. doi: https://doi.org/10.1016/j.quascirev.2006.01.010 